\title{
Detection of microorganisms with antibacterial activities from different industrial wastes and GC-MS analysis of crude microbial extract
}

\author{
Detecção de microrganismos com atividades antibacterianas de diferentes resíduos \\ industriais e análise por GC-MS do extrato microbiano bruto
}

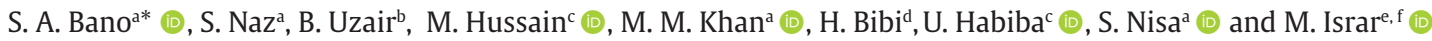 \\ ${ }^{a}$ The University of Haripur, Department of Microbiology, Khyber Pakhtunkhwa, Pakistan \\ bInternational Islamic University, Department of Biosciences, Islamabad, Pakistan \\ 'The University of Haripur, Department of Forestry and Wild Life, Khyber Pakhtunkhwa, Pakistan \\ ${ }^{\mathrm{d}}$ Agricultural University, Department of Soil and Environmental Sciences, Peshawar, Pakistan \\ ${ }^{\mathrm{e}}$ The University of Haripur, Department of Biology, Khyber Pakhtunkhwa, Pakistan \\ fHebei Normal University Shijiazhuang, College of Life Science, Hebei, PR China
}

\begin{abstract}
Many soil microorganisms' i.e., bacteria and fungi produce secondary metabolites called antibiotics. These are used for the treatment of some of the bacterial, fungal and protozoal diseases of humans. There is a need for isolation of a broad spectrum of antibiotics from microorganisms due to the emergence of antibiotic resistance. In the present study two antibiotic producing bacteria Klebsiella pneumoniae and Bacillus cereus were isolated from pharmaceutical and poultry feed industry of Hattar, Haripur Pakistan. Total 10 waste samples were collected from different industries (Marble, Ghee, Soap, Mineral, Steel, Poultry Feed, Pharmaceutical, Qarshi, Cosmetic and Glass). Thirty-three bacterial strains were isolated from industrial wastes of these ten different industries. Fourteen out of thirty-three bacterial strains exhibited antimicrobial activities against at least one of the test microbes considered in this study including Escherchia coli, Staphylococcus aureus and Salmonella typhi. The bacteria were isolated by standard serial dilution spread plate technique. Morphological characterization of the isolates was done by Gram staining. Nine bacterial isolates out of fourteen were initially identified as B. cereus and five as K. pneumoniae through biochemical characterization. The antibacterial activities were tested by well diffusion method. Maximum number of antibiotic producing bacteria were isolated from pharmaceutical and poultry feed industry based on the results of primary screening, the most potential isolates S9, S19, S20, S22 and S23 were selected for secondary screening. The maximum activity against $E$. coli and $S$. aureus was recorded by bacterial isolate S19 i.e zones of inhibition of $6.5 \mathrm{~mm}$ and $9 \mathrm{~mm}$ while $\mathrm{S} 20$ showed $7.5 \mathrm{~mm}$ and $6 \mathrm{~mm}$ zones respectively. Molecular identification was carried out on the basis of 16S rRNA sequence analysis. Finally, the isolates were identified as B. cereus accession number LC538271 and K. pneumoniae accession number MT078679. Analysis of bacterial extract S20 through GC-MS indicated the presence of 8 compounds of diverse nature and structure. Present study suggests that wastes of pharmaceutical and poultry feed industry may have antibiotic producing bacteria. These bacteria could be utilized for the production of antibiotics. B. cereus and K. pneumoniae isolated from wastes of poultry feed and pharmaceutical industries have the potential to produce antibiotics and could be used to control the microbial growth.
\end{abstract}

Keywords: antibiotic producing microorganisms, antibacterial activity, zone of inhibition, soil sample, well diffusion method, spread plate technique.

\begin{abstract}
Resumo
Muitos microrganismos do solo, ou seja, bactérias e fungos produzem metabólitos secundários chamados antibióticos. Eles são usados para tratamento de algumas doenças bacterianas, fúngicas e protozoárias em humanos. Há necessidade de isolamento de um amplo espectro de antibióticos de microrganismos devido ao surgimento de resistência aos antibióticos. No presente estudo, duas bactérias produtoras de antibióticos, Klebsiella pneumoniae e Bacillus cereus, foram isoladas da indústria farmacêutica e de ração avícola de Hattar, Haripur, Paquistão. Um total de 10 amostras de resíduos foi coletado de diferentes indústrias (mármore, ghee, sabão, mineral, aço, ração para aves, farmacêutica, Qarshi, cosmética e vidro). Trinta e três cepas bacterianas foram isoladas de resíduos industriais dessas dez diferentes indústrias. Quatorze das 33 cepas bacterianas exibiram atividades antimicrobianas contra
\end{abstract}

*e-mail: asma_baano@yahoo.com, Syeda.asma@uoh.edu.pk

Received: November 14, 2020 - Accepted: March 30, 2021 
pelo menos um dos micróbios de teste considerados neste estudo, incluindo Escherchia coli, Staphylococcus aureus e Salmonella typhi. As bactérias foram isoladas pela técnica de placa de diluição em série padrão. A caracterização morfológica dos isolados foi feita por coloração de gram. Nove isolados bacterianos de 14 foram inicialmente identificados como B. cereus e cinco como K. pneumoniae por meio de caracterização bioquímica. As atividades antibacterianas foram testadas pelo método de difusão em poço. 0 número máximo de bactérias produtoras de antibióticos foi isolado da indústria farmacêutica e de ração avícola com base nos resultados da triagem primária, os isolados mais potenciais S9, S19, S20, S22 e S23 foram selecionados para a triagem secundária. A atividade máxima contra E. coli e S. aureus foi registrada pelo isolado bacteriano S19, ou seja, zonas de inibição de 6,5 mm e $9 \mathrm{~mm}$, enquanto S20 mostrou zonas de 7,5 mm e $6 \mathrm{~mm}$, respectivamente. A identificação molecular foi realizada com base na análise da sequência $16 \mathrm{~S}$ rRNA. Finalmente, os isolados foram identificados como $B$. cereus número de acesso LC538271 e K. pneumoniae número de acesso MT078679. A análise do extrato bacteriano S20 por meio de GC-MS indicou a presença de oito compostos de natureza e estrutura diversas. O presente estudo sugere que resíduos da indústria farmacêutica e de ração para aves podem conter bactérias produtoras de antibióticos. Essas bactérias podem ser utilizadas para a produção de antibióticos B. cereus e K. pneumoniae isolados de resíduos de rações de aves e indústrias farmacêuticas têm potencial para produzir antibióticos e podem ser usados para controlar o crescimento microbiano.

Palavras-chave: microrganismos produtores de antibióticos, atividade antibacteriana, zona de inibição, amostra de solo, método de difusão em poços, técnica de espalhamento em placa.

\section{Introduction}

Microorganisms produce several secondary metabolites which play a very important role in human health. These bioactive compounds are present as bacteriosins and mycotoxins produced by bacteria and fungi. Actinomycetes have also been used for the production of important drugs like erythromycin, vancomycin, streptomycin and actinomycin etc (Falkinham 3RD et al., 2009). Most of the antibiotics are produced by soil microorganisms. Natural soil provides a best medium for the growth of antibiotics producing microorganisms. (Demain and Fang, 2000, Abbas et al., 2014). These Antibiotics have been incredibly useful for the treatment of some of the bacterial, fungal and protozoal diseases of human. The demand for new antibiotics has been increasing day by day due to the emergence of drug resistant pathogens. Pharmaceutical industry all over the world is producing more than one million tons antibiotics per annum. About five thousand and five hundred antibiotics have been discovered due to constant efforts made in this field (Kaur et al., 2014). Presently several micro-organisms are grown in artificial medias for the search of antibiotic producing microorganisms. A Streptomyces strain SJE177 was isolated from soil which exhibited the production of actinomycin (Euanorasetr et al., 2010). Waste soil is also considered a source of microorganisms and bioactive compounds producing micro-organisms were isolated from waste soils of India (Singh and Mishra, 2013). A large amount of microorganisms are found in the soil, as it is the most suitable environment for their survival (Chaudhary et al., 2013). Two most known inhibitory bacteria are Bacillus and Actinomycetes which are found predominantly in the soil which show antibiotic production by producing Bacitracin and Actinomycin correspondingly.

B. pumilus and B. subtilis have been reported to show antimicrobial activity against $S$. aureus and Micrococcus luteus (Tabbene et al., 2009). For better growth of microorganisms, the most favourable conditions of $\mathrm{pH}$, temperature, organic matter and moisture are required. Aminoglycosides, Penicillin, Macrolides, Glycopeptides, Cephalosporins and Tetracyclins are most common antibiotics (Demain, 2009). Bacillus species are found predominant in soil which inhibit the growth of a variety of microorganisms due to the formation of endospores which are resistant and also have importance for the production of essential antibiotics such as bacitracin etc. Different studies confirmed Bacillus species to produce antimicrobial compounds having pharmaceutical and biotechnological importance (Awais et al., 2007). Actinomycetes from soil are considered the best source of the production of a number of drugs including from actinomycin and streptomycin, to vancomycin and erythromycin. The variety of terrestrial actinomycetes are important in several areas of medicine and science for the production of antibiotics. Majority of the biologically active compounds isolated from actinomycete, have been arranged into numerous classes which are based on their structures including b-lactam i.e cephalosporins, ansamycins (e.g., rifampin). Erythromycin are macrolides, tetracycline while kanamycin and streptomycin are amino glycosides (Kayode and Sani, 2008). Streptomyces griseus is an additional microorganism found in the soil, which has the ability to produce bioactive compound known as streptomycin that shows the bactericidal activity against various harmful bacteria such as M. tuberculosis (Thakur et al., 2007). Over the ancient decades the bioactive compounds of these microorganisms have been utilized against number of bacterial infections. But as pathogens showed resistance to those previously available antibiotics, multi drug resistance is the most important problem of these days that is faced by everyone. So, there is a great requirement to discover novel antibiotics or to find out some other alternatives to fight against these pathogenic bacteria (Nithya and Pandian, 2010).

The objective of this study was to isolate antibiotic producing microorganism from different industrial wastes of Hattar, Haripur. Another objective of study was to find the predominantly found microbes in the waste soil samples of ten different industries which could how antibacterial activity against $S$. aureus, E. coli and S. typhi. 


\section{Material and Methods}

\subsection{Sample collection, preparation and isolation of bacteria}

For the isolation of antibiotic producing microorganisms, industrial waste soil samples were collected from ten different industries of Hattar. Approximately $1 / 2 \mathrm{~kg}$ of waste soil samples were collected for further processing. Samples were collected from the soil of crust and depth of 4 inches with the help of sterile spatula and placed in sterile polythene bags for transportation to Microbiology laboratory. Sample preparation was done through serial dilutions in a laminar air flow. Five sterile test tubes were taken for each sample, marked and labelled for each sample. A soil suspension is made by adding $1 \mathrm{~g}$ of dried soil sample in $10 \mathrm{ml}$ of distilled water in a first test tube and is vortexed. This stock solution was then diluted serially up to the dilution of $10^{-5}$ and $0.1 \mathrm{~mL}$ of diluted sample was inoculated on the sterile nutrient agar plates then incubated at $37^{\circ} \mathrm{C}$ for 24 hours in an incubator. For the isolation of pure cultures of bacterial strains, the sub culturing was done by using the sterile loop to pick the bacterial colonies having clear boundary and were streaked on the fresh nutrient agar plates by using streak plate method and were incubated at $37^{\circ} \mathrm{C}$ for 24 hours. The purified colonies were preserved using standard preservation methods.

\subsection{Microscopic and Biochemical characterization of selected bacteria}

After isolation of bacterial strains on Nutrient agar plates, strains were identified and characterized by morphological, cultural and biochemical tests using Bergay's manual as a reference (Vos et al., 2009). Microscopic and biochemical tests were performed to recognize the isolated strains. For microscopic identification gram staining technique was performed. Biochemical tests were used for the identification of bacterial isolates as described by Bergey's manual i.e. Catalase, Citrate, Oxidase, Urease, Indole etc.

\subsection{Antibacterial activity testing}

Antibacterial activity of the isolated bacterial strains was checked against three test organisms. Two Gram negative and one gram positive bacteria were used as test pathogens in this study and were collected from NESCOM hospital, Islamabad. For testing of antibacterial activity three test pathogens including E. coli, S. aureus and S. typhi were grown in nutrient broth. After inoculating LB with the test organisms and isolated bacterial strains in separate test tube, these were incubated at $37^{\circ} \mathrm{C}$ for 24 hours. Then after 24 hrs of incubation of the isolated bacterial strains and test organisms, antibacterial activity was checked through well diffusion method by using Mueller Hinton Agar. Well diffusion method was performed to observe the antibacterial action of the isolated strains. In this method sterile cotton buds were used to swab all three test pathogens on 3 different MHA plates, then by using sterile cork borer, four wells of the size of 9 to $10 \mathrm{~mm}$, were made on each plate. About $100-150 \mathrm{~mL}$ of culture supernatant of different isolated strains were loaded into different wells of each plate and incubated at $37^{\circ} \mathrm{C}$ for 24 hours. The zone of inhibition was checked after 24 hours of incubation. Finally, the zones was measured with the scale.

\subsection{Molecular identification of bacteria by $16 S$ rRNA amplification and sequencing}

Bacterial DNA was extracted according to the TIANamp Bacteria kit protocol by following the manufacturer's protocol. The universal primers (Forward primer): 5' CCTACGGGAGGCAGCAG 3') as well as reverse primer (5' TGGACTACCAGGGTATC 3') were used for the amplification of the 16S rRNA gene fragment. The PCR programme was as follows: Initial denaturation, $94^{\circ} \mathrm{C}$ for 5 min followed by 30 cycle in which one cycle consist of three different temperature $94^{\circ} \mathrm{C}$ for 30 second, $55^{\circ} \mathrm{C}$ for 30 second and $72^{\circ} \mathrm{C}$ for $1 \mathrm{~min}$ and final cycle for $72^{\circ} \mathrm{C}$ for $10 \mathrm{~min}$. The rRNA reaction mixture contained $1 \mu \mathrm{l}$ of DNA template $(10 \mathrm{ng}), 0.4$ microliter of each universal forward and reverse primers, 4 microliter of 6X Master Mix (containing Taq-DNA polymerase, $\mathrm{dNTPs}, \mathrm{MgCl}_{2}$ along with reaction buffers) and $14.2 \mu$ of autoclaved distilled water. The PCR product was observed by using gel electrophoresis.

\subsection{Sequencing and analysis of $16 S \mathrm{rRNA}$}

The amplified 16S rRNA gene fragment was purified and sequenced using DNA sequencing services (Macrogen, Korea). 16S rRNA sequence was analyzed by using Basic local alignment search tool (BLAST) available from the website of National Center for Biotechnology information (https://blast.ncbi.nlm.nih.gov) to identify the identical matches with existing characterized reference sequences.

\subsection{Phylogenetic analysis of isolated bacterial strains}

The sequences of the close hits were retrieved from $\mathrm{NCBI}$ and performed multiple sequence alignment by using Clustawl W. The aligned files were then exported in mega format. Neighbor-joining tree was constructed in MEGAX using default parameters and bootstrap values of 1000 .

\subsection{Gas Chromatography-Mass Spectrometry Analysis of Bacterial isolate S20}

The crude extracts of samples were used to evaluate their chemical composition using GC-MS. A 20-min run was conducted from initial temperature of $40{ }^{\circ} \mathrm{C}$ to the final temperature of $250^{\circ} \mathrm{C}$. The spectrum was noted in the range of $40-600 \mathrm{~m} / \mathrm{z}$. Peaks of various compounds eluted from the column of GC were recorded along with their retention time. Data was correlated with mass spectra of these compounds and database was searched for similar compounds with same retention time and molecular mass. Bioactivities of already reported natural compounds were studied and a comparison was made to correlate the activities of bacterial extract with their constituents.

\subsection{Statistical analysis of zones of inhibition}

One-way ANOVA was applied on zones of inhibition data for antibacterial activities by using SPSS software. Tukey test was used as a Post hoc test to compare each group with all the others. 


\section{Results}

3.1. Isolation and identification of bacterial isolates having antibacterial activity against test strains

Thirty-three bacterial strains were isolated from industrial wastes of ten different industries (Marble, Ghee, Soap, Mineral, Steel, Feed, Pharmaceutical, Qarshi, Cosmetic and Glass) (Figure . 1). Fourteen out of total thirty-three bacterial strains showed antimicrobial activities against at least one of the test microbes considered in this study including E. coli, S. aureus and S. typhi (Figure 2, Table 1). Gram staining and different biochemical tests exhibited the presence of nine isolated antibacterial strains as Bacillus sp., while the biochemical tests of five samples revealed identity with klebsiella sp. (Table 2). klebsiella sp. isolated from pharmaceutical industry was gram negative as it showed pink rods on gram staining and positive for catalase, citrate, urease, fermentation tests (Figure 3, Table 2). The oxidase indole and motility tests exhibited by klebsiella sp. were negative (Table 2). Bacillus strains isolated from poultry feed industry were gram positive rods (purple rods) and positive for catalase, citrate and motility, while negative for oxidase, urease and indole tests (Figure 3, Table 2). Fermentation tests exhibited by Bacillus strains were positive for sucrose, fructose and glucose, while negative test with mannitol (Table 2). The molecular identification was carried out on the basis of $16 \mathrm{~S}$ rRNA sequence analysis. The results
A

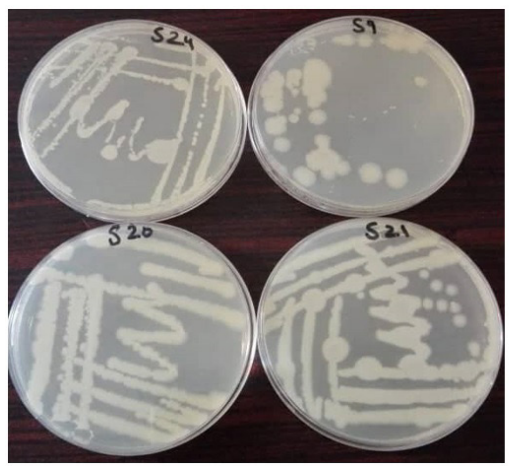

B

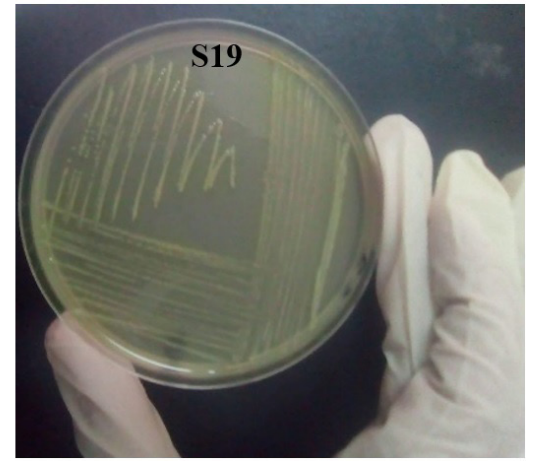

Figure 1. Growth of bacterial strains on nutrient agar. (A) Strain S9 isolated from waste of soap industry, S21 from feed industry, S20 and S24 from Pharmaceutical industry; (B) S19 strain isolated from poultry feed waste.

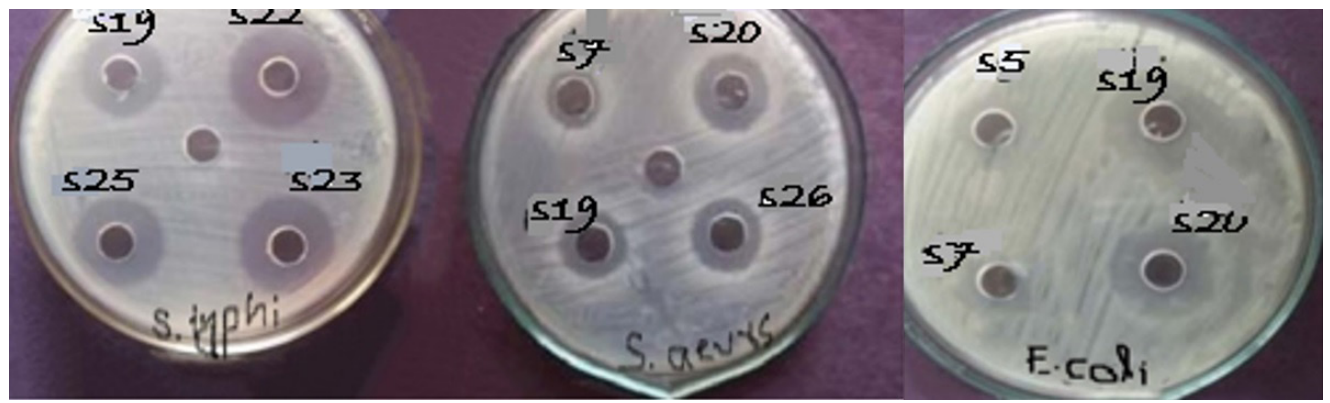

Figure 2. Antibacterial activity of isolated strains as depicted by clear zones of bacterial isolates. S5, S7, S19, S20, S22, S23, S25, S26 showed the isolated bacterial strains from industrial waste samples for testing antibacterial activities against S. typhi, S.aureus and E.coli.

Table 1. Zones of clearance exhibited by different bacterial isolates against test pathogens (E. coli, S. aureus and S. typhi).

\begin{tabular}{|c|c|c|c|c|c|c|c|c|c|c|c|c|c|c|}
\hline \multirow[b]{2}{*}{ S.No } & \multicolumn{14}{|c|}{ Zones of clearance exhibited by different bacterial isolates against three pathogens ( $\mathrm{mm}$ ) } \\
\hline & $\begin{array}{c}\text { Test } \\
\text { pathogens }\end{array}$ & S2 & S5 & S7 & S15 & S19 & S20 & S21 & S22 & S23 & S25 & S26 & S27 & S33 \\
\hline 1 & E. coli & 5.5 & 2 & 1 & $\mathbf{0}$ & 6.5 & 7.5 & 0 & 6 & 5 & 0 & 0 & $\mathbf{0}$ & 2 \\
\hline 2 & S. aureus & $\mathbf{0}$ & 5.5 & 6 & 4 & 9 & 6 & 4 & 4.5 & 4 & 5.5 & 6.5 & 5.5 & 4.5 \\
\hline 3 & S. typhi & 0 & 1 & 2.5 & 0 & 5.5 & 0 & 0 & 7.5 & 7.5 & 7.5 & 5.5 & 3.5 & 2 \\
\hline
\end{tabular}

Note: S2, S5, S7, S15, S19, S20, S21, S22, S23. S25, S26, S27 and S33 are different bacterial isolates. S. aureus is Staphylococcus aureus. S. typhi is Salmonella typhi. E. coli is Escherchia coli. Text highlighted in bold exhibited the zone of inhibition by K. pneumonia against three test pathogens E. coli, S. aureus and S. typhi. while normal text showed the zones of inhibition by B. cereus against three test pathogens. 
Table 2. Biochemical, Motility and Morphological tests of different isolated bacterial strains.

\begin{tabular}{|c|c|c|c|c|c|c|c|c|c|c|c|c|c|c|}
\hline S.No & $\begin{array}{l}\text { Biochemical } \\
\text { tests }\end{array}$ & S2 & S5 & S7 & S15 & S19 & S20 & S21 & S22 & S23 & S25 & S26 & S27 & S33 \\
\hline 1 & Oxidase & - & - & - & - & - & - & - & - & - & - & - & - & - \\
\hline 2 & Catalase & + & + & + & + & + & + & + & + & + & + & + & + & + \\
\hline 3 & Citrate & + & + & + & + & + & + & + & + & + & + & + & + & + \\
\hline 4 & Urease & + & - & - & + & - & + & - & - & + & - & - & + & - \\
\hline 5 & Indole & - & - & - & - & - & - & - & - & - & - & - & - & - \\
\hline 6 & Suc. Ferm. & + & + & + & + & + & + & + & + & + & + & + & + & + \\
\hline 7 & Fruc. Ferm. & + & + & + & + & + & + & + & + & + & + & + & + & + \\
\hline 8 & Gluc. Ferm. & + & + & + & + & + & + & + & + & + & + & + & + & + \\
\hline 9 & Mannitol & + & - & - & + & - & + & - & - & + & - & - & + & - \\
\hline 10 & Motility test & NM & M & M & NM & M & NM & M & M & NM & M & M & NM & M \\
\hline 11 & $\begin{array}{c}\text { Morphology } \\
\text { Gram staining }\end{array}$ & GN & GP & GP & GN & GP & GN & GP & GP & GN & GP & GP & GN & GP \\
\hline
\end{tabular}

Note: S2, S5, S7, S15, S19, S20, S21, S22, S23. S25, S26, S27 and S33 are different bacterial isolates. NM is employed for Non motile, M for Motile. + sign shows positive test, - sign shows negative test result. Suc. Ferm is employed for Sucrose fermentation, Fruc. Ferm. is employed for fructose fermentation. Gluc. Ferm. is employed for Glucose fermentation. Different bacterial isolates have been isolated from industrial wastes of ten different industries.

Table 3. Identification of antibacterial activity showing bacteria.

\begin{tabular}{|c|c|c|c|c|c|}
\hline S.no & Source & Isolates & $\begin{array}{l}\text { 16SrRNA amplified } \\
\text { region length }\end{array}$ & $\begin{array}{c}\text { \% Identity/ } \\
\text { similarity }\end{array}$ & NCBI Accession no. \\
\hline 1 & Poultry feed wastes & S19 & 490 bp & $\begin{array}{c}99 \% \text { with Bacillus } \\
\text { cereus }\end{array}$ & LC538271 \\
\hline 2 & $\begin{array}{c}\text { Pharmaceutical } \\
\text { industrial wastes }\end{array}$ & S20 & 271 bp & $\begin{array}{l}98 \% \text { with Klebsiella } \\
\text { pneomoniae }\end{array}$ & MT078679 \\
\hline
\end{tabular}
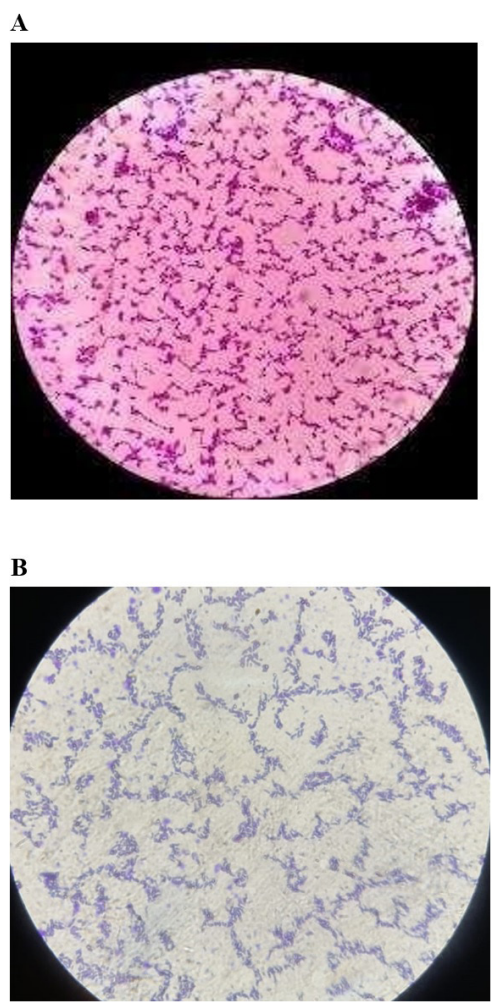

Figure 3. Colony morphology of isolated antibiotic producing bacterial strains. Figure $(A)$ shows gram negative rods while spore forming purple rods have been exhibited in figures (B).

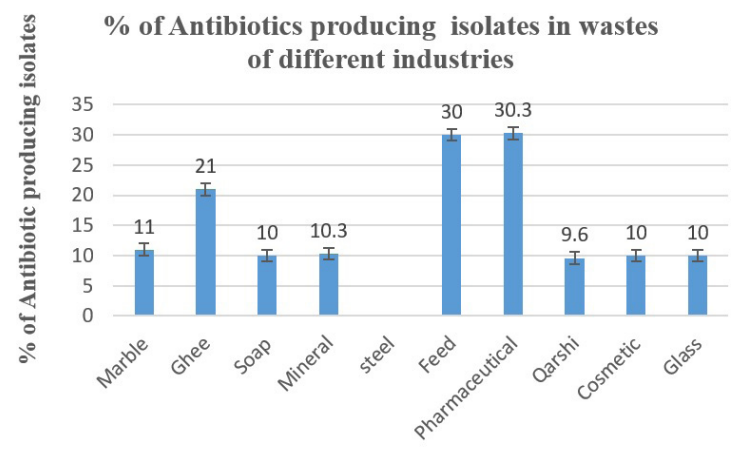

Wastes of different Industries

Figure 4. Percentages of antibiotic producing isolates in the wastes of different industries of Hattar, Haripur. Error bars indicate standard errors of mean values $(n=3)$.

of DNA sequencing were submitted to GenBank with the accession number of MT078679 for klebsiella pneumonia (S20) and LC538271 (S19) for Bacillus cereus (Table 3). Finally the isolates were identified as Bacillus cereus accession number LC538271 and klebsiella pneumonia accession number MT078679.

The highest number of antibiotic producing bacteria were isolated from the Pharmaceutical and feed industry which is depicted in Figure 4 while no bacterium was isolated from the wastes of steel industry. Although some bacteria were also isolated from the wastes of other industries including ghee, marble, cosmetics, soap, mineral, Qarshi, cosmetics 
and glass but their number was lower as compared to the poultry feed and pharmaceutical industries (Figure 4). The presence of antibiotic producing bacteria depends on the presence of some energy source or nutrients. In the waste samples of steel industry, no nutrients or energy source is available for the growth of bacteria, hence no bacteria were isolated from wastes of steel industry. Less number of isolated bacteria in wastes of marble, cosmetics, soap, mineral, Qarshi, cosmetics and glass industries also show low nutrients and less amount of energy sources present there. Like all living things, bacteria need food, water and the proper environment to live and grow. A bacterium must have an energy source, a source of carbon and other required nutrients, and a permissive range of physical conditions such as $\mathrm{O}_{2}$ concentration, temperature, and $\mathrm{pH}$.

The experiment for testing antibacterial activities was repeated thrice. Significant values of zones of inhibition were observed at $95 \%$ confidence interval (mean difference was significant at $0.05 \%$ level). The bacterial strains isolated from Poultry feed and Pharmaceutical industries exhibited significantly higher values of inhibition zones as compared to the Marble, Ghee, Soap, Mineral, steel, Qarshi, cosmetics and glass industries for at least one pathogen. It was depicted by sig. 0.00 values $(0.00 \leq 0.05)$ obtained by performing ANOVA with Tukey test by using SPSS. No bacterial strain was isolated from waste samples of steel industry.

\subsection{GC-MS analysis of bacterial extracts}

GC-MS analysis of ethyl alcohol extracts of Bacterial sample S20 exhibited the presence of bioactive compounds. The presence of several compounds with known biological activity was found in the bacterial extracts analyzed and references are provided in Table 4 describing where compounds observed in such type of study were previously found.

\section{Discussions}

Soil is known to harbor antibiotic producing microorganisms which may be of great medicinal importance that include $M$. s roseus, Brevibacterium sp., B. subtilus, B. anthracis, B. cereus etc. (Rafiq et al., 2018). In order to explore the potential of different industrial wastes of Hattar, Haripur to produce antibiotic producing bacterial strains, we carried out a study to identify any bacteria with potential to synthesize bioactive compounds against 3 pathogenic bacteria (S. aureus, S. typhi and E. coli). Results revealed the presence of two antibacterial activity exhibiting bacterial strains K. pneomonae and B. cereus from the wastes of pharmaceutical and poultry feed industry (Table 3). The isolated bacteria belonged to Phylum Proteobacteria and firmicutes. Several researchers have

Table 4. Major constituents of bacterial extracts S20, as depicted by GC-MS analysis.

\begin{tabular}{|c|c|c|c|c|c|}
\hline S. No & Retention time & Compound name & Mol. Weight & Formula & Biological Activity \\
\hline 1 & 3.08 & $\begin{array}{l}3 \text { Chloropropionic } \\
\text { acid } 2 \text { Pentadecyl } \\
\text { ester }\end{array}$ & $318 \mathrm{~g} / \mathrm{mol}$ & $\mathrm{C} 18 \mathrm{H} 3502 \mathrm{Cl}$ & $\begin{array}{l}\text { Antibacterial activity of } \\
\text { its derivative is reported } \\
\text { (Fadhil et al., 2018) }\end{array}$ \\
\hline 2 & 3.08 & $\begin{array}{c}\text { Octadecane } 1 \\
\text { Chloro }\end{array}$ & $288 \mathrm{~g} / \mathrm{mol}$ & $\mathrm{C} 13 \mathrm{H} 37 \mathrm{Cl}$ & $\begin{array}{l}\text { Antibacterial activity of } \\
\text { its derivative is reported } \\
\text { (Boussaada et al., 2008) }\end{array}$ \\
\hline 3 & 3.44 & $\begin{array}{l}\text { Benzyl } \\
\text { Isoproponyl Ether }\end{array}$ & $148 \mathrm{~g} / \mathrm{mol}$ & $\mathrm{C} 10 \mathrm{H} 120$ & $\begin{array}{c}\text { Antibacterial and } \\
\text { antifungal activity of its } \\
\text { derivative is reported } \\
\text { (Mohammed et al., 2016) }\end{array}$ \\
\hline 4 & 3.44 & $\begin{array}{l}\text { Benzene (3, } 3 \\
\text { Dimethylbutyl }\end{array}$ & $162 \mathrm{~g} / \mathrm{mol}$ & C12H18 & $\begin{array}{l}\text { Antimicrobial activity of its } \\
\text { derivative is reported (Wintola } \\
\text { and Afolayan, 2017) }\end{array}$ \\
\hline 5 & 3.55 & $\begin{array}{l}\text { Propionic acid } 2 \\
\text { (Amnooxy) }\end{array}$ & $105 \mathrm{~g} / \mathrm{mole}$ & C3H703N & $\begin{array}{l}\text { Antimicrobial activity of } \\
\text { its derivative is reported } \\
\text { (Katariya et al., 2019) }\end{array}$ \\
\hline 6 & 3.55 & $\begin{array}{l}2 \text { Propanone } \\
\text { 2- }(2,4 \\
\text { Dimethylphenyl } \\
\text { hydrazone })\end{array}$ & $176 \mathrm{~g} / \mathrm{mole}$ & C11H16N2 & $\begin{array}{l}\text { Antimicrobial activity of } \\
\text { its derivative is reported } \\
\text { (Hassan et al., 2017) }\end{array}$ \\
\hline 7 & 3.64 & Benzene Eicosyle & $358 \mathrm{~g} / \mathrm{mole}$ & $\mathrm{C} 24 \mathrm{H} 46$ & $\begin{array}{c}\text { Antimicrobial activity of its } \\
\text { derivative is reported (Wintola } \\
\text { and Afolayan, 2017) }\end{array}$ \\
\hline 8 & 3.64 & $\begin{array}{c}8 \text { Phenyl Octanoic } \\
\text { acid }\end{array}$ & $220 \mathrm{~g} / \mathrm{mole}$ & $\mathrm{C} 14 \mathrm{H}_{2} \mathrm{OO}_{2}$ & $\begin{array}{c}\text { Antibacterial and } \\
\text { antifungal activity of its } \\
\text { derivative is reported } \\
\text { (Mohammed et al., 2016) }\end{array}$ \\
\hline
\end{tabular}

The compounds showed resemblance with the natural products of bacterial origin (Faridha Begum et al., 2016). 
indicated the importance of Proteobacteria, Firmicutes as antibiotic producers. Bacillus species and some other spore forming bacteria carry genes for the production of antibiotics (Stein, 2005). Bacitracin produced by Bacillus species inhibited both E. coli and S. aureus. A great diversity of secondary metabolites are produced by Bacillus species isolated from soil (Awais et al., 2007). Hassan et al., (2014) also conducted similar study for the isolation of antibiotic producing microorganisms against different test pathogens.

In the present study antibiotic producing bacteria were isolated from waste soil of different industries of Hattar, Haripur. Bacillus cereus isolated from poultry feed industry exhibited clear zone of inhibition against test pathogenic microorganisms (E. coli, S.aureus and S. typhi). This is demonstrated in Table 1 by observing the zones of inhibition of isolated bacterial samples S19 and S22 against test pathogens. This finding is in accordance with Ahmed et al. (2013), who screened soil microorganisms for detection of antibiotic producing bacteria. They identified Bacillus species as antibiotic producing bacteria from soil (Ahmed et al., 2013). Screening of microorganisms has been done through relatively rapid and simple methods for antibiotic production. Soil bacteria and fungi may show an important feature of antibiotic production. The bacteria isolated from soil show antibiotic activity under normal growth conditions and are found to inhibit some gram-positive as well as gram-negative organisms. A neighbor joining tree depicting the phylogenetic relationship of isolated bacterial strains S19 and S20 revealed the relationship of isolated bacteria with different strains of $B$. cereus and $K$. pneumonae (Figures $5 \& 6$ ).

In the present study we also identified K. pneumonia. Bacterial samples S20 and S23 were identified as potential antibiotic producing strains of $k$. pneumonia. Zones of inhibition of $7.5 \mathrm{~mm}$ and $4 \mathrm{~mm}$ were exhibited by K. pneumonia (Sample S20 isolated from wastes of pharmaceutical industry) against test pathogens $E$. coli and S. aureus (Table 1). Another isolated strain of K. pneumonia S23 also exhibited zones of inhibition against test pathogens E. coli, S. aureus and S. typhi. These isolated bacterial strains of $K$. pneumoniae and B. cereus could be utilized for the production of antimicrobial compounds against $S$. aureus, E. coli as well as S. typhi.

Industrial wastes of pharmaceutical and feed industry may also show other antibiotic producing microorganisms. Present study is in accordance with Kishore and Vijayalakshmi (2018). They isolated micro-organisms from sewage samples collected from Andhra Pradesh, Visakhapatnam. Three strains of antibiotic producing bacteria were isolated (AntC1, AntC3 and AntC8), which exhibited antibacterial activity against $S$. aureus as well

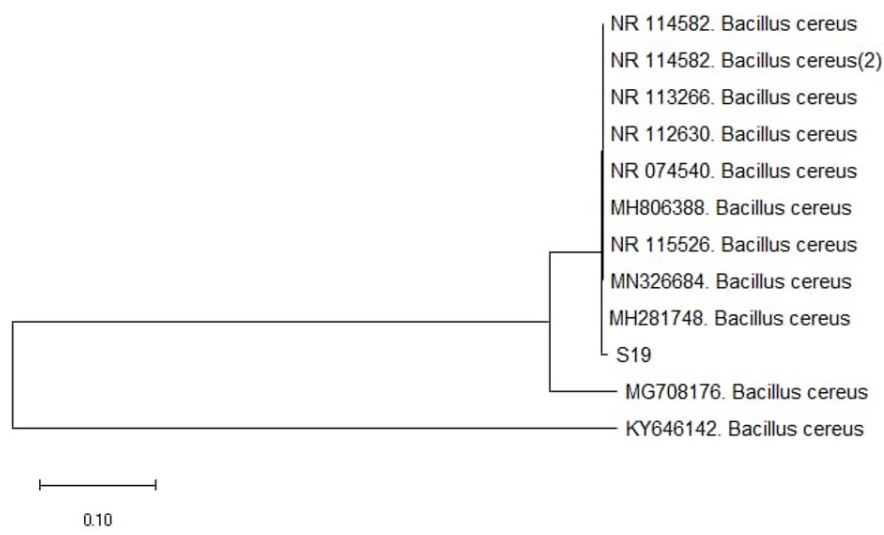

Figure 5. A neighbor-joining tree depicting the phylogenetic relationship of isolated bacterial strain S19. The tree has been constructed using MEGA X.

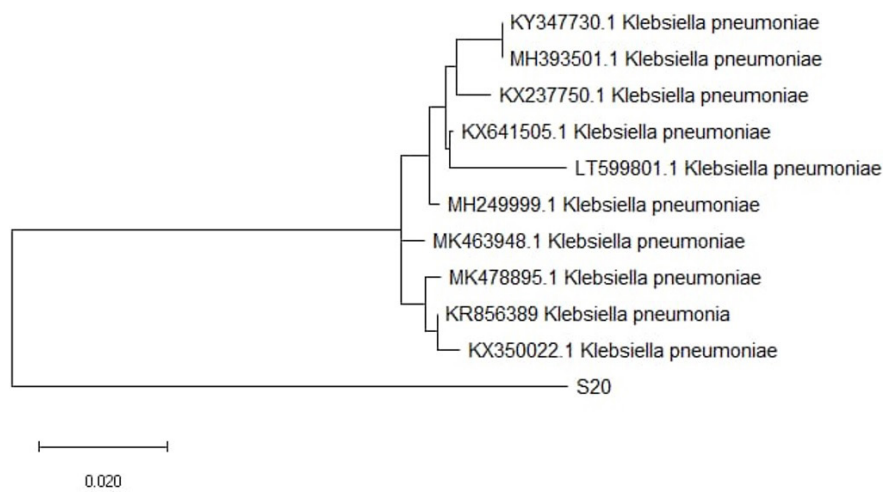

Figure 6. A neighbor-joining tree depicting the phylogenetic relationship of isolated bacterial strain S20. The tree has been constructed using MEGA X. 
as E. coli (Kishore and Vijayalakshmi, 2018). A similar study was also conducted by Kumar et al. (2018), who screened different bacteria to observe the antagonistic and antibacterial activity against several test organisms through various methods. Four isolated strains of bacteria were found to show high antibiotic activity against test organisms (B. subtilis and S. aureus) (Kumar et al., 2018). Gislin et al. (2018) revealed a study on antibiotic producing micro-organisms. They isolated bacteria from soil and tested their antibiotic ability against six human pathogens including S. aureus, E. coli, P.aeruginosa, Enterococcus sp, K. pneumoniae, and Acineto-bacter sp. Each isolate exhibited antibacterial activity against $S$. aureus and species of Enterococcus (Gislin et al., 2018). Abbas et al. (2014) revealed a study on soil samples collected from different locations of Bangalore for the isolation and characterization of novel antibiotic producing microorganisms against Bacillus strains. They identified Bordetella, Achromobacter and Streptomyces as antibiotics producers (Demain and Fang, 2000). Rafiq et al. (2018) also demonstrated the presence of antibiotic producing bacteria and fungi from soil (Hassan et al., 2017). The isolated strains of bacteria were identified as B. subtilis, M. roseus, B. anthracis Brevibacterium sp., and $B$. cereus through biochemical characterization and fungal isolates were recognized as, Cladosporium cladosporides, Epicoccum nipponicum, Tricho-cladium opacum A. niger and Rhizocotania sp.

To identify the bioactive compounds of the isolated bacterial extract S20, the GC-MS analysis was performed which indicated the presence of esters, alcohols, alkanes, amines and other derivatives in the isolated bacterial extract (Table 4). These findings are in accordance with previous reports. Production of bioactive compounds in bacterial strains isolated from wastes of Pharmaceutical and poultry feed industry could be used for the preparation of antibiotics against some resistant pathogens. Present research project also demonstrates the presence of potential antibiotic producing microorganisms in the waste of pharmaceutical and feed industry. It may be inferred that more research may be conducted by increasing the sample size and selecting different areas to isolate some other antimicrobial bacterial strains. This may broaden the horizon of research for antibiotic producing microorganisms.

\section{Conclusions}

Wastes of pharmaceutical and poultry feed have the potential to produce bacteria exhibiting activities against pathogens such as E. coli, S. aureus and S. typhi. The isolated strain (S19) of B. cereus accession number LC538271 could be utilized for the production of bioactive compounds against $S$. aureus, Salmonella spp. and S. typhi. Similarly identified strain of $K$. pneumoniae accession number MT078679 could be used to produce antibacterial compounds against S. aureus and E. coli. Understanding the mechanism of action of isolated bioactive compounds from these bacteria will broaden the horizon of research in antibiotic drug discovery. Future work will be concentrated on the isolation and detailed characterization of bioactive compounds from different bacterial strains.

\section{Acknowledgements}

The authors wish to thank the Department of Microbiology, $\mathrm{UOH}$, for providing facilities to conduct this research work.

\section{References}

ABBAS, S., SENTHILKUMAR, R. and ARJUNAN, S., 2014. Isolation and molecular characterization of microorganisms producing novel antibiotics from soil sample. European Journal of Experimental Biology, vol. 4, pp. 149-155.

AHMED, R. N., SANI, A. H., AJIJOLAKEWU and ALAMU, F. B., 2013. Soil screening for antibiotic - producing microorganisms. Advances in Environmental Biology, vol. 7, no. 1, pp. 7-11.

AWAIS, M., ALI SHAH, A., ABDUL, H. and HASAN, F., 2007. Isolation, identification and optimization of Bacillus sp. Pakistan Journal of Botany, vol. 39, pp. 1303-1312.

BOUSSAADA, O., AMMAR, S., SAIDANA, D., CHRIAA, J., CHRAIF, I., DAAMI, M., HELAL, A.N. and MIGHRI, Z., 2008. Chemical composition and antimicrobial activity of volatile components from capitula and aerial parts of Rhaponticum acaule DC growing wild in Tunisia. Microbiological Research, vol. 163, no. 1, pp. 87-95. http://dx.doi.org/10.1016/j.micres.2007.02.010. PMid:17482441.

CHAUDHARY, H.S., YADAV, J., SHRIVASTAVA, A.R., SINGH, S., SINGH, A.K. and GOPALAN, N., 2013. Antibacterial activity of actinomycetes isolated from different soil samples of Sheopur (A city of central India). Journal of Advanced Pharmaceutical Technology \& Research, vol. 4, no. 2, pp. 118-123. http://dx.doi. org/10.4103/2231-4040.111528. PMid:23833752.

DEMAIN, A.L. and FANG, A., 2000. The natural functions of secondary metabolites. Advances in Biochemical Engineering/Biotechnology, vol. 69, pp. 1-39. http://dx.doi.org/10.1007/3-540-44964-7_1. PMid: 11036689.

DEMAIN, A.L., 2009. Antibiotics, natural products essential to human health. Medicinal Research Reviews, vol. 29, no. 6, pp. 821-842. http://dx.doi.org/10.1002/med.20154. PMid:19291695.

EUANORASETR, J., NILVONGSE, A., TANTIMAVANICH, S., NIHIRA, T., IGARASHI, Y. and PANBANGRED, W., 2010. Identification and characterization of soil-isolated Streptomyces SJE177 producing actinomycin. The Southeast Asian Journal of Tropical Medicine and Public Health, vol. 41, no. 5, pp. 1177-1187. PMid:21073039.

FADHIL, L., KADHIM, S.A.H. and HAMEED, I.H., 2018. Detection of bioactive secondary metabolites produced by Bacillus subtilis using gas Chromatography-Mass spectrometry technique. Indian Journal of Public Health Research and Development, vol. 9, no. 8, pp. 1097. http://dx.doi.org/10.5958/0976-5506.2018.00877.X.

FALKINHAM 3RD, J.O., WALL, T. E., TANNER, J. R., TAWAHA, K., ALALI, F. Q., LI, C., and OBERLIES, N. H., 2009. Proliferation of antibiotic-producing bacteria and concomitant antibiotic production as the basis for the antibiotic activity of Jordan's red soils. Applied and Environmental Microbiology, vol. 75, no. 9, pp. 2735-2741. http://dx.doi.org/10.1128/AEM.00104-09. PMid: 19286796.

FARIDHA BEGUM, I., MOHANKUMAR, R., JEEVAN, M. and RAMANI, K., 2016. GC-MS analysis of bioactive molecules derived from Paracoccus pantotrophus FMR19 and the antimicrobial activity against bacterial pathogens and MDROs. Indian Journal of Microbiology, vol. 56, no. 4, pp. 426-432. http://dx.doi. org/10.1007/s12088-016-0609-1. PMid:27784938.

GISLIN, D., SUDARSANAM, D., ANTONY RAJ, G. and BASKAR, K.. 2018. Antibacterial activity of soil bacteria isolated from Kochi, India 
and their molecular identification.Journal, Genetic Engineering E Biotechnology, vol. 16, no. 2, pp. 287-294. http://dx.doi. org/10.1016/j.jgeb.2018.05.010. PMid:30733737.

HASSAN, S.A., HANIF, E. and ZOHRA, R.R., 2014. Isolation and screening of soil bacteria for potential antimicrobial activity. FUUAST Journal of Biology, vol. 4, no. 2, pp. 217-219.

HASSAN, S.W.M., ELSERSY, N.A., ABDELWAHAB, A.E.-S. and ALI, M.A., 2017. Statistical optimization and valuable applications of bioactive compounds produced by marine Pseudo alteromonas piscicida. Journal of Applied Pharmaceutical Science, vol. 7, no. 10, pp. 84-93.

KATARIYA, D., ASHID, M., SHARMA, B.K. and JOSHI, A., 2019. Synthesis, characterization and biological activity of some indole substituted propanoic acid. Journal of Chemistry and Chemical Sciences, vol. 9, no. 7, pp. 206-213. http://dx.doi. $\operatorname{org} / 10.29055 / \mathrm{jccs} / 714$.

KAUR, S., KAUR, J. and PANKAJ, P.P., 2014. Isolation and characterization of antibiotic producing microorganisms from soil samples of certain area of Punjab region of India. International Journal of Pharmaceutical and Clinical Research, vol. 6, no. 4, pp. 312-315.

KAYODE, R.M.O. and SANI, A., 2008. Physicochemical and proximate composition of mango (Mangifera indica) kernel cake fermented with mono-culture of fungal isolates obtained from naturally decomposed mango kernel. Life Science Journal, vol. 5, no. 4, pp. 55-63.

KISHORE, K. and VIJAYALAKSHMI, M., 2018. Isolation, morphological and biochemical characterization of antibiotic producing bacteria from various sewage sites of Visakhapatnam, Andhra Pradesh. The Pharma Innovation Journal, vol. 7, no. 11, pp. 287-291.

KUMAR, D., SRIVASTAVA, A., CHANDRA, N., PANDEY, A. and KUMAR, S., 2018. Isolation, screening and characterization of bacteria having antibacterial activity from industrial waste effluent. American Journal of Biomedical Sciences, vol. 10, no. 1

MOHAMMED, G.J., KADHIM, M.J. and HUSSEIN, H.M., 2016. Characterization of bioactive chemical compounds from Aspergillus terreus and evaluation of antibacterial and antifungal activity. International Journal of Pharmacognosy and Phytochemical Research, vol. 8, no. 6, pp. 889-905.
NITHYA, C. and PANDIAN, S.K., 2010. Isolation of heterotrophic bacteria from Palk Bay sediments showing heavy metal tolerance and antibiotic production. Microbiological Research, vol. 165, no. 7, pp. 578-593. http://dx.doi.org/10.1016/j.micres.2009.10.004. PMid:20015629.

RAFIQ A., KHAN, S.A., AKBAR, A., SHAFI, M., ALI, I., REHMAN, F.U., RASHID, R., SHAKOOR, G. and ANWAR, M., 2018. Isolation and identification of antibiotic producing microorganisms from soil. International Journal of Pharmaceutical Sciences and Research, vol. 9, pp. 1002-1011.

SINGH, A.P. and MISHRA, S., 2013. Isolation and biochemical characterization of antibiotic producing microorganism from waste soil samples of certain industrial areas of India. IOSR Journal of Pharmacy and Biological Sciences, vol. 5, no. 6, pp. 80-90.

STEIN, T., 2005. Bacillus subtilis antibiotics: structures, syntheses and specific functions. Molecular Microbiology, vol. 56, no. 4, pp. 845-857. http://dx.doi.org/10.1111/j.1365-2958.2005.04587.x. PMid: 15853875.

TABBENE, O., SLIMENE, I.B., DJEBALI, K., MANGONI, M.L., URDACI, M.C. and LIMAM, F., 2009. Optimization of medium composition for the production of antimicrobial activity by Bacillus subtilis B38. Biotechnology Progress, vol. 25, no. 5, pp. 1267-1274. http:// dx.doi.org/10.1002/btpr.202. PMid:19634172.

THAKUR, D., YADAV, A., GOGOI, B.K. and BORA, T.C., 2007. Isolation and screening of Streptomyces in soil of protected forest areas from the states of Assam and Tripura, India, for antimicrobial metabolites. Journal de Mycologie Médicale, vol. 17, no. 4, pp. 242-249. http://dx.doi.org/10.1016/j.mycmed.2007.08.001.

VOS, P., GARRITY, G., JONES, D., KRIEG, N.R., LUDWIG, W., RAINEY, F.A., SCHLEIFER, K.H. and WHITMAN, W., eds, 2009. BERGEY'S manual of systematic bacteriology. New York: Springer. The Firmicutes, vol. 3.

WINTOLA, O. B. and AFOLAYAN, A. J., 2017. Chemical constituents and biological activities of essential oils of Hydnora africana Thumb Used to Treat Associated Infections and Diseases in South Africa. Applied Sciences, vol. 7, no. 5, pp. 443. https:// doi.org/10.3390/app7050443. 